\title{
AGRICULTURAL ENGINEERING AT UNICAMP: UNDERGRADUATE STUDENT DROPOUT ANALYSIS
}

\section{ROBERTO TESTEZLAF ${ }^{1}$}

\begin{abstract}
Nowadays, dropping out in B.Sc. courses practically occurs in all Universities of the contemporary world. Undergraduate student withdraw could means several losses as, to the student, not to graduate, to the teacher, for not accomplishing his goal as educator, to the university, for not attending its mission, to the society, economic and social losses and also to the family for unfulfilling the dreams. The objective of this research is to present a quantitative study on the dropping out rate in the Agricultural Engineering B.Sc. program (BSAGENG) at State University of Campinas (UNICAMP), seeking to contribute to the understanding of this issue. It has been determined the dropping out rate from 1995 to 2006 based on the university official data, by employing four different methods of calculation. Three of the methods revealed that dropping out rate is very close to the graduation index, i.e., close to 50\%. Regardless of the adopted method for the dropping rate estimation and the statistics demonstrating that the agricultural engineering undergraduate course at UNICAMP figures falls within similar courses normality in Brazil, it should be recognized that a public institution of education should be concerned in presenting such figures. A detailed and deep analysis must be outlined in further studies seeking for specific actions aiming to reduce dropping out process.
\end{abstract}

KEYWORDS: B.Sc. courses, higher education, dropout rate.

\section{ENGENHARIA AGRÍCOLA NA UNICAMP: ANÁLISE DA EVASÃO NO CURSO DE GRADUAÇÃO}

RESUMO: O problema de evasão de estudantes dos cursos de graduação está presente praticamente em todas as Universidades do mundo contemporâneo. A desistência do aluno por um curso superior significa prejuízo para si próprio ao não se diplomar, para o professor que não atinge sua meta como educador, para a universidade pelo não atendimento de sua missão, para a sociedade pelas perdas sociais e econômicas e, também, para a família, pelo sonho não realizado. O objetivo deste trabalho é apresentar um estudo quantitativo sobre a evasão do curso de Engenharia Agrícola da UNICAMP, buscando contribuir para o entendimento dessa questão. A partir de dados oficiais da UNICAMP, determinou-se a taxa de evasão para o período compreendido entre os anos de 1995 e 2006, utilizando quatro metodologias de cálculo. Três das metodologias utilizadas demonstram que a taxa de evasão do curso de Engenharia Agrícola da UNICAMP tem o valor muito próximo ao índice de titulação, ou seja, próxima de 50\%. Independentemente do método adotado para a estimativa da evasão e de as estatísticas demonstrarem que os números do curso de Engenharia Agrícola da UNICAMP estão dentro da normalidade de cursos de graduação similares no Brasil, pode-se afirmar que é preocupante para uma instituição pública de ensino apresentar os valores obtidos. Um maior aprofundamento das causas deve ser delineado em estudos posteriores para que ações específicas busquem a redução desse processo.

PALAVRAS-CHAVE: curso de graduação, ensino superior, taxa de evasão.

\footnotetext{
${ }^{1}$ Eng $^{\mathrm{o}}$ Agrícola, Prof. Titular, Universidade Estadual de Campinas, Campinas - SP, bob@ @eagri.unicamp.br. 


\section{INTRODUCTION}

Undergraduate student dropping out occurs in all higher educational institutions in the world as reported by SILVA FILHO et al (2007). According to BRASIL (1996) dropout is defined as the student definitive leaving from the undergraduate program in which he is enrolled, without graduation. The analysis of its causes is extremely complex due to its association to a number of factors showing individual as well as interrelated contributions to the process. The BSAGENG program offered by the State University of Campinas was officially established in the year of 1975 and initially administrated by the College of Food and Agricultural Engineering, starting in the year of 1976 and from 1985 on by the newly created College of Agricultural Engineering (FEAGRI). Although a qualitative study was not conduced on the student dropout causes in the BSAGENG at UNICAMP, the numbers of graduating students of every year indicates significant parcels of students leaving the course, generating constant concerns in identifying the possible reasons as well as to search for adequate solutions. The objective of this work was to contribute to the understanding of this issue, presenting a quantitative study on the student dropout from 1995 to 2006 and to discuss possible actions toward the reduction of those figures.

\section{METHODOLOGY}

From official academic data of the students enrolled in the BSAGENG program from the year of 1995 up to 2006, as provided by the Academic Board of the State University of Campinas, a statistical analysis has been conducted to estimate the course dropout rate. Obtained data allowed to classify dropped out students in the following groups: withdrawing by abandonment of the program (i.e., a student who does not officially enrolled in any discipline without requesting a semester licensing or without the right of licensing or by his own initiative had abandoned his position within the University) or by registration cancellation (student who does not fulfilled academic regulations as required by the University, or at the student request), or transferred (to another course at UNICAMP or to another Institution). As there is no consensus on how to measure the dropout rate in higher educational institutions allowing academic comparisons, in this work it was decided to apply four traditional methodologies to calculate the above referred parameter:

1. Graduation index: it relates the total number of students who graduated in the course program with the total number of entering students since the BSAE program was first offered. The total dropout rate would be the complement of this index, since it measures the number of students who, having entered in a specific course program did not graduate at the end of the time limit established by the university;

2. Annual dropout rate: the relationship between the number of students who leave the course program during the academic year to the total number of students enrolled for the first time in the same period.

3. University standard dropout rate: it is an index employed by UNICAMP, defined as the percentage of students who withdraw from the course program in a given academic year in relation to the total number of students enrolled in the course program at the end of the period under consideration.

4. Unbalanced dropout rate: it relates the number of non-graduated students in a determined academic year with the number of students who had enrolled in the course five years before, i.e., the required graduation time for Brazilian engineering course programs.

\section{RESULTS AND DISCUSSION}

Figure 1 exhibits the evolution of the number of students who dropout from the BSAGENG in the period of 1995 to 2005 , according to the classification adopted by the UNICAMP Academic Board. 


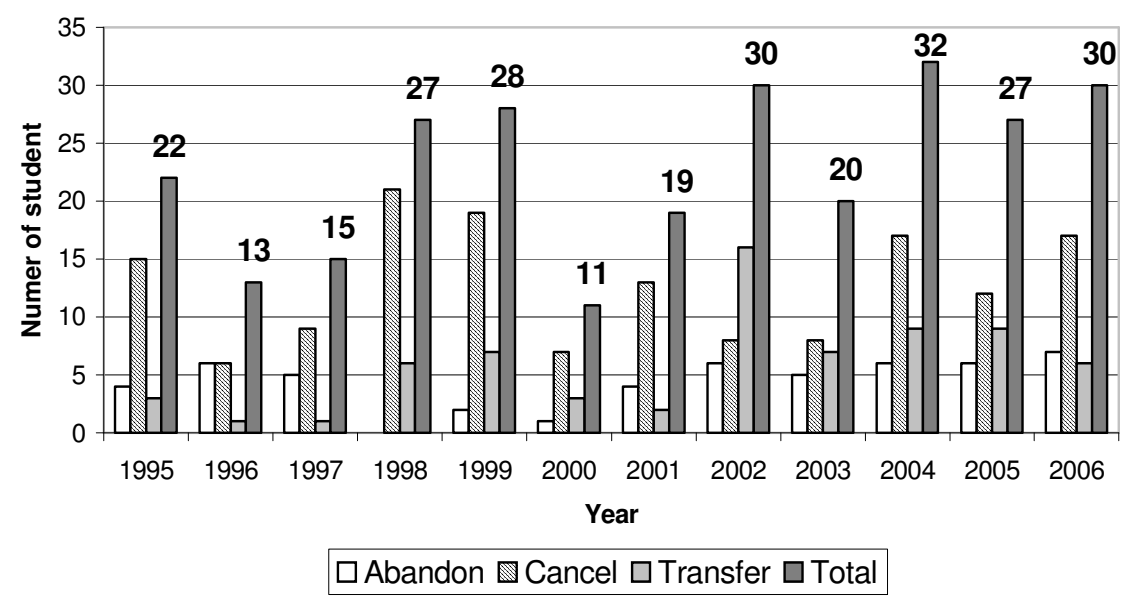

FIGURE 1. Annual student dropping out from BSAGENG program at UNICAMP, from 1995 to 2006.

It can be observed in Figure 1 that, from 2002 there was a trend in the number of evasion to remain around the value of 30, emphasizing that from 1999 to 2002 the course program started to offer 60 admission places which, in 2003, have been increased to 70 admission places. Another important point to be noted is the number of students showing cancelled enrollment reaching an average of $55 \%$ of dropout students. This number is always higher than the number of the students who have abandoned the course program, except in 1996, and transferred students, except in 2002. These numbers indicate that the main dropout reason is not the fulfillment of academic rules as required by the University, or at the student request, but it was caused mainly by their low academic performance in the two initial semesters of the course program. Additionally, transferred students had meant $26 \%$ of dropout number and $19 \%$ for abandonment.

Graduation index: Since the total number of students enrolled in the BSAGENG until the year of 2002 was 975 and by the year of 2006 which was the year in which the class of 2002 was expected to graduate, the total number of degrees granted reached the value of 522, it can be stated that the graduation index of the BSAGENG was $53.5 \%$ with yielding a dropout rate of $46.5 \%$;

Annual dropout rate: Table 1 presents the values of this parameter for the period understood between 1995 and 2006.

TABLE 1. Annual dropout rate from 1995 to 2006.

\begin{tabular}{cccc}
\hline Year & Withdraw Students & Entering Students & Dropout (\%) \\
\hline 1995 & 22 & 41 & 53.7 \\
1996 & 13 & 43 & 30.2 \\
1997 & 15 & 37 & 40.5 \\
1998 & 27 & 40 & 67.5 \\
1999 & 28 & 45 & 62.2 \\
2000 & 11 & 69 & 15.9 \\
2001 & 19 & 64 & 29.7 \\
2002 & 30 & 66 & 45.5 \\
2003 & 20 & 75 & 26.7 \\
2004 & 32 & 72 & 44.4 \\
2005 & 27 & 73 & 37.0 \\
2006 & 30 & 76 & 39.5 \\
\hline Average & 22.2 & --- & 41.1 \\
\hline
\end{tabular}


From the data shown on Table 1, it can be noted that the average annual dropout rate for the period was $41.1 \%$, i.e., from every ten students who joined the course each year, approximately 4 students withdraw at the end of the first year.

Standard dropout rate: Table 2 shows the UNICAMP standard dropout rate of the BSAGENG course for the period understood from 1995 to 2006.

TABLE 2. Standard dropout rate for the BSAGENG Course program at UNICAMP, from 1995 to 2006.

\begin{tabular}{cccc}
\hline Year & Withdraw Students & Enrolled Students & Dropout (\%) \\
\hline 1995 & 22 & 205 & 10.7 \\
1996 & 13 & 207 & 6.3 \\
1997 & 15 & 205 & 7.3 \\
1998 & 27 & 200 & 13.5 \\
1999 & 28 & 193 & 14.5 \\
2000 & 11 & 216 & 5.1 \\
2001 & 19 & 235 & 8.1 \\
2002 & 30 & 263 & 11.4 \\
2003 & 20 & 288 & 6.9 \\
2004 & 32 & 335 & 9.6 \\
2005 & 27 & 348 & 7.8 \\
2006 & 30 & 363 & 8.3 \\
\hline Average & 22.2 & --- & 9.1 \\
\hline
\end{tabular}

Table 2 shows that the standard dropout rate average associated to the period was $9.1 \%$. The value of this parameter for others UNICAMP Undergraduate Programs referring to the period between 1993 and 2003 was 6.5\%. Therefore, the dropout rate of the BSAGENG is above the university average. It is stressed out that the university careers exhibiting lower percentage of dropout rate are medicine $(0.99 \%)$, civil engineering ( $1.5 \%)$, dentistry $(1,5 \%)$, electrical engineering $(1.7 \%)$, and those with a higher dropout percentage were: physics $(14.3 \%)$, mathematics $(10.6 \%)$ and programs related to Social Sciences (9.3\%).

Unbalanced dropout rate: Table 3 presents the values of this parameter for the period of 1995 to 2006.

TABLE 3. Unbalanced dropout rate for the BSAGENG at UNICAMP, from 1995 to 2006.

\begin{tabular}{ccccc}
\hline Year & Graduate & Class Entries & Class Dropout & Dropout (\%) \\
\hline 1995 & 18 & 45 & 27 & 60.0 \\
1996 & 29 & 47 & 18 & 38.3 \\
1997 & 26 & 41 & 15 & 36.6 \\
1998 & 22 & 41 & 19 & 46.3 \\
1999 & 25 & 41 & 16 & 39.0 \\
2000 & 30 & 43 & 13 & 30.2 \\
2001 & 21 & 37 & 16 & 43.2 \\
2002 & 20 & 40 & 20 & 50.0 \\
2003 & 9 & 45 & 36 & 80.0 \\
2004 & 27 & 69 & 42 & 60.9 \\
2005 & 35 & 64 & 29 & 45.3 \\
2006 & 48 & 66 & 18 & 27.3 \\
\hline Average & --- & --- & 22.4 & 46.4 \\
\hline
\end{tabular}


The analysis of this parameter shows an average of $46.4 \%$, with an average graduation rate of $53.6 \%$, which is identical to the total dropout rate estimated through the total graduation index. Figures obtained for the BSAGENG are close to the results obtained by INSTITUTO LOBO (2007), which showed that the Brazilian graduation rate of $51 \%$ in 2005, with $49 \%$ of dropout rate.

Three of the employed methodologies to estimate the dropout rate showed values for the BSAGENG program very close to the graduation index value, or next to $50 \%$. According to BRAZIL (1996) the factors affecting the student dropout can be classified in three types; first, those related to the student himself, second, those related to course and the institution and finally, the external ones related to socio-cultural as well as economic factors. In the case of Agricultural Engineering, where the largest dropout percentage is related to the student enrollment cancellation by the University, it can be stated that actions intending to take care of the incoming student would have a significant effect on that process. However, the definition of more specific strategies leading to the increase of the graduation rates and reducing dropout rates can only be achieved from further studies aiming to generate a better definition of the prevailing factors in the case of the BSAGENG course program at FEAGRI.

\section{CONCLUSIONS}

Regardless of the adopted method to estimate the dropout rate, the statistics showed that the numbers for the BSAGENG course program at UNICAMP are within the normality of similar undergraduate programs in Brazil. However, the institution should be concerned in presenting such numbers. Since the main cause of course dropout is related to the student enrollment cancellation by the University due to student academic performance during the first two semesters, actions directed to support entering students would have a significant effectiveness in that process. A deep cause analysis must be outlined in further studies seeking for specific actions supporting the process reduction.

\section{REFERENCES}

BRASIL. Ministério de Educação e Cultura. Secretaria de Ensino Superior. Diplomação, retenção e evasão nos cursos de graduação em instituições de ensino superior públicas ANDIFES/ABRUEM, SESU, MEC. Brasília, 1996. 134 p.

INSTITUTO LOBO. Instituto Lobo para o Desenvolvimento da Educação, da Ciência e Tecnologia. Disponível em: <http://www.institutolobo.org.br/instituto/artigos/artigol.asp >. Acesso em: 10 jan. 2007.

SILVA FILHO, R.L.L.; MOTEJUNAS, P.R.; HIPÓLITO, O.; LOBO, M.B.C.M. A evasão no ensino superior brasileiro. Cadernos de Pesquisa, São Paulo, v.37, n.132, p.641-659, 2007.

UNICAMP. Universidade Estadual de Campinas. Disponível em:

$<$ http://www.unicamp.br/unicamp/canal_aberto/clipping/outubro2004/clipping041031_correiopop.h tml>. Acesso em: 22 feb. 2006. 